Lendenfeld, studies on Sponges: $(\mathbf{r})$ the vestibule of Dendrilla cavernosa, sp.n. ; (2) on Raphyrus luxonii, a new gigantic species from Port Jackson ; (3) Halme tingens ; (4) two cases of mimicry in Sponges (plates 39-43). - On recent changes in the forest flora of the interior of New South Wales; notes how the Pine Scrub (Callitris) rapidly supersedes the angiospermatous trees. The larva of a beetle (Diadoscus erythrurus) in part keeps the pine in check; drought seems favourable to the development of the beetle, or at least, by affecting the vegetation of the pine, enable its ravages to be more felt.-On the Australian fresh-water Rhizopoda,-On an Alga forming a pseudomorph of a siliceous Sponge.-On the dorsal papillæ of Onchidium.-Fourth addendum to the Australian Hydromedusæ. -E. P. Ramsay and J. Douglas-Ogilby, descriptions of many new or rare fishes. - George Masters, catalogue of the described Coleoptera of Australia, part 2.-N. de MiklouhoMaclay and Wm. Macleay, the Plagiostomata of the Pacific, part 3 (plates 45,46 ).-A. Sidney Olliff: Trogositidæ of Australia.-On a new species of Chrysophanus.-On Australian Ptinidæ. -W. A. Haswell, on some Australian Polychæta, part I (plates 50-55).-E. Meyrick, Australian Micro-Lepidoptera.-J. Brazier, a new Ochidium. - New land and freshwater Mollusca from New Guinea.

Second series, vol. i. part I, with 6 plates (May 25, I886).E. P. Ramsay and J. Douglas-Ogilby, descriptions of new Australian fishes; new species of fish from New Guinea; a new Coris from the New Hebrides.-E. P. Ramsay, on a new genus and species of fresh-water tortoise from the Fly River, New Guinea (plates 3-6).-George Masters, catalogue of Australian Coleoptera, part 3.-F. Ratte, Crioceras australe, Moore(?), a Lower Cretaceous fossil from Queensland (plates I, 2). Wm. Macleay, the insects of the Fly River, New Guinea. -C. W. de Vis, on some Geckos in the Queensland Museum. -A. S. Olliff, on a new Aphanipterous insect from New South Wales. -Wm. A. Haswell, on the myology of Petaurista taguanides.-Capt. F. W. Hutton; the Mollusca of the Pareora and Oamaru systems of New Zealand.

Proceedings of the Royal Society of Queensland, vol. ii. parts I and 2, June 1886, contain, among others:-W. E. Armit, notes on the philology of the islands adjacent to the southeastern extremity of New Guinea (pp. 2-12), and on the Papuans (pp. 78-116), - C. W. De Vis, on the bones and teeth of a large extinct lizard (pp. 25-3I, plates $1-3$ ). - On an extinct Ornithorhynchus (pp. 35-40, plate 4).-On some new species of Salarias, and on a new species and genus of lizard (pp. 56-6I). -On a fossil Saurian (pp. I8I-I 22, plates Io-1 5).- Henry Tryon, on Queensland harvesting-ants.-W. A. Tully, short account of the measurement of the base-line in connection with the trigonometrical survey of Queensland.-Baron von Miiller, on a new tiliaceous tree (Elaocarpus Bancroftii) from North Eastern Australia

Proceedings of the Royal Society of Tasmania for 1885 (Tasmania, 1886). - From the records of the Proceedings it is interesting to learn that, though the Society has lost the exclusive control over the Museum and Gardens, which now are managed by trustees, some of whom are elected by the Society, yet the work of the Society continues to develop, and its library to increase. This volume is accompanied by a sketch-map, coloured, giving the general geological features of Tasmania, by C. P. Sprent and R. M. Johnston; and a geological chart, by $\mathrm{Mr}$. Johnston, showing the proposed provisional classification of the stratified rocks of Tasmania and their equivalents elsewhere.-Among the more important papers we note the following:-R. M. Johnston, various memoirs on the geology and palæontology of Tasmania.-R. A. Bastow, on the mosses and Jungermania of Tasmania.-W. F. Pettard, new Tasmanian marine shells. - Baron F. von Müller, notes on J. J. H. de Labillardière (with a portrait).-Capt. Shortt, earthquakephenomena in Tasmania. - T. Stevens, on boring for coal in Tasmania.

\section{ON THE OCCURRENCE OF CELLULOSE IN TUBERCULOSIS}

CELLULOSE, the principal constituent of the vegetable cell-wall, has been found to occur also in some animals the mantle of Phallusia mamillaris and of Cynthia, and the external coat of Salpa consist mainly of tunicin, or animal cellulose. Now a further very valuable contribution to our knowledge of the occurrence of this body has been made in Vienna by Herr Ernst
Freund, working at Prof. E. Ludwig's laboratory. Freund has succeeded in preparing from some of the organs and blood of tuberculous persons a substance exactly resembling cellulose, and showing all the reactions which have hitherto been described as peculiar to the latter. The reactions employed were the following:-(I) Conversion of cellulose when dissolved in concentrated sulphuric acid into dextro e on boiling with dilute sulphuric acid ; (2) resistance if treated with Schultze's reagent, a mixture of nitric acid and chlorate of potassium; (3) yielding of a collodion-like mass by the action of nitric acid and ether; (4) assuming a blue colour by the action of iodine in presence of concentrated sulphuric acid or chloride of zinc solution ; (5) assuming a violet colour by the action of a naphthol when dissolved in concentrated sulphuric acid (Molisch's reaction); (6) insolubility in common (indifferent) solvents (dilute alkalies); (7) solubility in a solution of cupric hydroxide in ammonia. The substance obtained from miliary tubercles and from the blood of tuberculous persons was subjected to ultimate analysis in three cases, and yielded between $45^{\circ} \mathrm{I} 2$ and $44^{\circ} 70$ per cent. $C$, and between $6.4 \mathrm{I}$ and 6.19 per cent. $\mathrm{H}$; while $44^{\circ} 74$ per cent. $\mathrm{C}$ and 6.17 per cent. $\mathrm{H}$ corresponds to $\mathrm{C}_{6} \mathrm{H}_{10} \mathrm{O}_{5}$. A quantitative determination of the cellulose of the tubercles has not been made. The researches were carried out on material from twenty-five tuberculous and thirty non-tuberculons cases. The tuberculous material (lungs, spleen, peritoneum with miliary tubercles, blood) embraced cases of conglomerated as well as of infiltrated tuberculosis in the different stages of the disease. The non-tuberculous material examined was taken partly from healthy organs, partly from organs affected by various diseases-as, e.g., from pneumonia, emphysema, pulmonary gangrene--and failed to show any of the reactions described above. Carcinomatous, sarcomatous, lupoid, syphilitic, and other non-tuberculous granulations were also examined with negative results. From his i esearches Herr Freund makes the suggestion that in tuberculous growths and in the blood of tuberculous persons cellulose forms an intrinsic constituent. We need not refer to the importance and suggestiveness of Freund's discovery for pathological science, making further researches on this subject very de irable.

\section{DISINFECTION BY HEAT}

THE Annual Report for 1884 of the Medical Officer of the Local Government Board contained a memoir, by Dr. H. F. Parsons, on the subject of disinfection by heat. Of this memoir the leading points are here given.

In considering the applicability of heat as a means of disinfection, several distinct questions present themselves for solution. It has first of all to be determined what degree of heat and duration of exposure are necessary under different conditions, as of moisture and dryness, in order to destroy with certainty the activity of the contagia of infectious diseases.

We have next to ascertain how the required degree of heat may be made to penetrate through bulky and badly conducting articles, e.g. of clothing and bedding, for the disinfection of which the application of heat is especially employed.

We have also to learn whether such articles can be submitted to the required degree of heat without injury, for if not, disinfection presents little advantage over destruction.

After giving a résumé of the results of previou; experiments to ascertain the degree of heat necessary to destroy the contagia of infectious diseases, from those of Dr. Henry published in the Philosophical Magasine for 1831, to those of Koch and his coadjutors (Mitlheilungen aus dem kaiserlichen Gesundheitsamte, Berlin, I88I), the author states the results of a series of experiments made by him in conjunction with Dr. Klein, who prepared the infective materials, and, after these had been exposed to disinfecting processes, tested the results by inoculation on animals ; control inoculations with unheated portions of the same materials being also in all cases made.

The following were the infective materials employed :-

(I) Blood of guinea-pig dead of anthrax, containing bacillus anthracis without spores.

(2) Pure cultivation of bacillus anthracis in rabbit broth, without spores.

(3) Cultivation of bacillus anthracis in gelatine, with spores.

(4) Cultivation of bacillus of swine fever (infectious pneumoenteritis of the pig) in pork broth.

(5) Tuberculous pus, from an abscess in a guinea-pig which had been inoculated with tubercle. 